\title{
If-then Planning in Sports: A Scoping Review
}

\author{
Maik Bieleke ${ }^{1}$, Wanja Wolff ${ }^{1,2}$, Chris Englert ${ }^{2,3}$, and Peter M. Gollwitzer ${ }^{4,5,6}$ \\ ${ }^{1}$ Department of Sport Science, Sport Psychology, University of Konstanz, Konstanz, Germany \\ ${ }^{2}$ Department of Educational Psychology, University of Bern, Bern, Switzerland \\ ${ }^{3}$ Department of Sport Sciences, Sport Psychology, TU Dortmund University, Dortmund, Germany \\ ${ }^{4}$ Department of Psychology, New York University, New York, USA \\ ${ }^{5}$ Department of Psychology, University of Konstanz, Konstanz, Germany \\ ${ }^{6}$ Institute of Psychology, Leuphana University Lüneburg, Lüneburg, Germany
}

This is the author version of an accepted manuscript that has been published in the Zeitschrift für Sportpsychologie:

Bieleke, M., Wolff, W., Englert, C., \& Gollwitzer, P.M. (2021). If-then planning in sports: A scoping review. Zeitschrift für Sportpsychologie, 28(3), 109-120. https://doi.org/10.1026/1612-5010/a000336.

\section{Author Note}

Correspondence concerning this article should be addressed to Maik Bieleke, Department of Sport Science, University of Konstanz, Universitätsstraße 10, 78464 Konstanz, Germany. E-mail: maik.bieleke@uni-konstanz.de 
2 If-then planning (implementation intentions) describes a self-regulatory strategy that helps

3 people to attain their goals across a variety of domains, such as achieving physical activity goals.

4 Based on such beneficial effects, if-then plans are anecdotally discussed as a strategy to

5 enhance sports-related performance as well. However, this discussion currently lacks an

6 empirical basis. We therefore conducted a scoping review to identify experimental research on

7 if-then planning effects on sports-related performance, potential moderators of these effects,

8 the methodological approaches used, and the suitability of the available evidence for assessing

9 the effectiveness of if-then planning in sports. Based on a search of four online databases, we

10 identified a set of eleven studies that investigated if-then planning in experimental research

11 with sports-related performance as outcome measure. Six of these studies focused on if-then

12 planning in endurance tasks, the remaining studies investigated sports performance beyond

13 endurance. The samples were often small and comprised university students, and conclusions

14 regarding the effectiveness of if-then planning for improving sports-related performance were

15 rather heterogeneous. Still, the majority of studies shed light on tentative mechanisms (e.g.,

16 perceptions of effort and pain, arousal) and moderators (e.g., athletes' beliefs about their

17 performance limits, feasibility of the behavior) of if-then planning in sports, guiding future

18 research regarding the question of when and for whom if-then-planning might be a beneficial

19 strategy. Based on these findings, we identify potentials and pitfalls when using if-then plans to

20 enhance sports-related performance, discuss promising routes for future research, and derive

21 practical implications for athletes and coaches.

22

Keywords: if-then planning, implementation intentions, self-control, sport performance, 
23 scoping review, psychological interventions 


\section{Zusammenfassung}

25 Wenn-Dann Pläne (Implementierungsintentionen, engl. „Implementation Intentions“) sind eine

26 selbstregulatorische Strategie, die Menschen beim Erreichen ihrer Ziele in vielen Domänen

27 unterstützt, z.B. im Kontext körperlicher Aktivität. Basierend auf solchen positiven Effekten

28 werden Wenn-Dann-Pläne anekdotisch als Strategie zur Leistungssteigerung auch im Sport

29 diskutiert. Allerdings fehlt dieser Diskussion derzeit eine empirische Grundlage. Wir haben

30 daher einen Scoping Review durchgeführt, um experimentelle Forschung zu Effekten von

31 Wenn-Dann-Plänen auf die sportbezogene Leistung, mögliche Moderatoren dieser Effekte, die

32 verwendeten methodischen Ansätze und die Eignung der verfügbaren Evidenz zur Beurteilung

33 der Wirksamkeit von Wenn-Dann-Plänen im Sport aufzuzeigen. Basierend auf einer Suche in

34 vier Online-Datenbanken identifizierten wir elf Studien, die Wenn-Dann-Pläne in

35 experimenteller Forschung mit sportbezogener Leistung als Ergebnismaß untersuchten. Sechs

36 dieser Studien konzentrierten sich auf Wenn-Dann-Pläne bei Ausdaueraufgaben, die restlichen

37 Studien untersuchten sportliche Leistungen jenseits der Ausdauer. Die Stichproben waren oft

38 klein und bestanden aus Universitätsstudierenden, und die Schlussfolgerungen bezüglich der

39 Effektivität der Wenn-Dann-Planung zur Verbesserung der sportbezogenen Leistung waren eher

40 heterogen. Die Mehrzahl der Studien gibt jedoch Aufschluss über mögliche Mechanismen (z.B.

41 Wahrnehmung von Anstrengung und Schmerz, Erregung) und Moderatoren (z.B.

42 Überzeugungen der Athlet_innen über ihre Leistungsgrenzen, Durchführbarkeit des Verhaltens)

43 von Wenn-Dann-Plänen im Sport. Das kann die zukünftige Forschung dahingehend informieren,

44 wann und für wen die Wenn-Dann-Planung eine vorteilhafte Strategie sein könnte. Basierend

45 auf diesen Erkenntnissen identifizieren wir Potenziale und Fallstricke beim Einsatz von Wenn- 
46 Dann-Plänen zur sportlichen Leistungssteigerung, diskutieren vielversprechende Wege für

47 zukünftige Forschung und leiten praktische Implikationen für Sportler_innen und Trainer_innen $48 \mathrm{ab}$.

49 Schlüsselworte: Wenn-Dann Pläne, Implementierungsintentionen, Implementation

50 Intentions, Selbstkontrolle, sportliche Leistung, Scoping Review, psychologische Interventionen 


\section{If-then Planning in Sports: A Scoping Review}

Volitionally controlling dominant impulses or automatic behavioral tendencies in sports-

53 related settings does not always work effectively (for an overview, see Englert, 2019). For

54 instance, picture the increasing muscle fatigue during a marathon: In order to keep going,

55 runners have to volitionally override the impulse to interrupt this rather straining act. So how

56 can athletes be supported to effectively follow through with their sports-related goals? One

57 promising strategy is if-then planning (often referred to as implementation intentions,

58 Gollwitzer, 1999).

If-then planning is a self-regulatory strategy that helps people to attain their goals

across a variety of domains (Gollwitzer, 2014; Gollwitzer \& Sheeran, 2006). For instance, about

61 half of the people who have the intention to exercise on a regular basis fail to act upon this

62 intention (Rhodes \& Bruijn, 2013) - which is but one example of the notorious "intention-

63 behavior gap" that pervades many areas of life in the health, professional, and interpersonal

64 domain (Sheeran \& Webb, 2016). Making if-then plans like "If I come home from the office,

65 then I will go for a run in the park" has been repeatedly shown to narrow this gap with respect

66 to physical activity (PA; Bélanger-Gravel et al., 2013; da Silva et al., 2018). Thus, if-then planning

67 qualifies as a viable self-regulatory strategy for increasing regular PA.

68 However, people who are already physically active and regularly engage in sports often

69 adjust their goals and raise their personal bar, often goals that pertain to the level of

70 performance: beating their personal best, achieving a certain performance in a competition, or

71 improving their technical skills (e.g., Franck et al., 2018). Such goals are likely to be relevant at

72 various levels of ability and aspiration and across different sports. Like the goal to engage in 
73 physical activity in the first place (Englert \& Rummel, 2016), attaining these goals requires

74 effective self-regulation (Englert, 2016; Wolff, Hirsch, et al., 2021): In order to improve one's

75 finishing time in a race, for instance, one must resist the urge to slow down and stick to one's

76 pacing strategy even when it gets effortful and aversive towards the end of the race. This

77 suggests that athletes might benefit from if-then plans to effectively strive for their

78 performance-related goals. The effects of implementation intentions on the PA intention-

79 behavior gap have been systematically investigated in several studies and are meanwhile well

80 established (reviews by Bélanger-Gravel et al., 2013; Rhodes \& Bruijn, 2013). However, it is

81 currently unclear to what extent such evidence exists for if-then planning effects on improving

82 performance in sports-related domains other than PA. Accordingly, we conducted a scoping

83 review of the available empirical evidence, which allows us to systematically map research on

84 this topic, collect tentative findings about if-then planning effects and their moderators, discuss

85 potentials and pitfalls when using if-then plans to enhance sports performance, and to derive

86 practical implications as well as promising routes for future research.

87 If-Then Planning: What is It and Why Does It Work?

When making if-then plans, people think about a goal-relevant situation and mentally

89 link it to a goal-directed behavior in an if-then format (i.e., "If Situation S occurs, then I will

90 perform Behavior B"). As such, if-then planning complements goals that merely specify a

91 desired outcome or behavior (i.e., "I want to perform Behavior B / attain Outcome O") by

92 conditioning a behavioral response on the occurrence of a critical situation. This critical

93 situation might be a good opportunity to act towards a goal or an obstacle that hinders goal

94 pursuit. 
Making if-then plans facilitates the attainment of goals by virtue of two cognitive

96 processes. First, thinking about the critical situation enhances its cognitive accessibility (Aarts et

97 al., 1999), directing attention to the situation and making it easier to detect (Achtziger et al.,

98 2012; Janczyk et al., 2015). Second, linking the situation to the intended behavior creates a

99 strong associative link, which is thought to automate the initiation of the respective goal-

100 directed behavior (e.g., Bayer et al., 2009; Brandstätter et al., 2001; Gollwitzer \& Brandstätter,

101 1997). Both processes have been shown to jointly mediate the beneficial effects of if-then

102 planning on goal attainment by automating the detection of the situation and the initiation of

103 the behavior (e.g., Webb \& Sheeran, 2007).

104 The Potential Relevance of If-then Planning in the Domain of Sports

105

It is commonly assumed that if-then planning is a beneficial strategy in sports (e.g., Brick

106 et al., 2016; McCormick et al., 2018). This assumption seems plausible, given that attaining

107 goals in sports is likely subject to many of those challenges for which if-then planning is known

108 to be effective (for a general overview see Gollwitzer \& Oettingen, 2011; for an overview

109 specific to endurance sports see Wolff, Bieleke, \& Schüler, 2019). First, if-then planning helps to

110 get started even when performing the goal-directed behavior is rather aversive (e.g., Milne et

111 al., 2002) or the critical situation is easy to miss (e.g., Webb \& Sheeran, 2004). Such situations

112 arise frequently in sports, for instance, when athletes have to increase their speed despite

113 feeling exhausted or need to recognize opportunities to exploit their opponents' mistakes.

114 Second, if-then planning helps to stay on track when the going gets tough (e.g., Legrand et al.,

115 2017). For instance, making if-then plans helps to deal with negative emotions (Schweiger Gallo

116 et al., 2009), which is of crucial importance for sports-related performance (Jones, 2003). Third, 
117 if-then planning allows people to instigate deliberative processes (Martiny-Huenger et al., 2016)

118 and to acquire information systematically (Bieleke et al., 2020). This can be crucial for flexibly

119 responding to changing circumstances during a competition, such as the need to change one's

120 strategy. Finally, making if-then plans automates the initiation of intended behaviors, which

121 makes their execution less dependent on information processing capabilities in the planned

122 situation (e.g., Webb \& Sheeran, 2003) and it helps to volitionally control more impulsive

123 processes (e.g., Thürmer et al., 2020). This is especially beneficial in sports when behaviors

124 must be initiated under considerable stress (e.g., distractions or time restrictions) or when

125 automatic responses must be regulated (e.g., the urge to slow down; c.f. Wolff, Bieleke, \&

126 Schüler, 2019).

127 Thus, from a theoretical point of view, if-then plans are a very promising self-regulatory

128 strategy to help deal with the action-control demands of sports. Consequently, sporting

129 federations (e.g., Calder, 2009), applied sport psychologists (e.g., Brick et al., 2016; McCormick

130 et al., 2018), and the media (e.g., Gregoire, 2016) endorse the application of if-then plans to

131 deal with these multiple demands. These endorsements are typically substantiated with

132 reference to if-then planning research outside of the sports domain. However, it is not a priori

133 evident that findings from basic psychological research or from other fields of applied

134 psychology directly translate to the context of sports and exercise, where people oftentimes

135 have to regulate strong aversive sensations (e.g., pain, effort, and fatigue; Bali, 2015). We

136 hypothesized that the available literature would be scarce and provide rather heterogeneous

137 results. This provides the main rationale for conducting this scoping review, in which we

138 address the following questions: What is the available empirical evidence for the assumption 
139 that if-then planning improves sports-related performance? What is known about the

140 conditions (moderators) and processes (mediators) of such effects? What are the potentials

141 and pitfalls of using if-than plans in applied sport settings that can be derived from these

142 findings? What are the current gaps in knowledge and methodology that should be addressed

143 in future research? By addressing these questions, this scoping review of if-then planning

144 effects on sport-related performance will be highly important for theorists and practitioners

145 alike.

\section{Methods}

Our review was based on the PRISMA guidelines for scoping reviews (PRISMA-ScR;

148 Tricco et al., 2018), which is freely accessible online (http://www.prisma-

149 statement.org/Extensions/ScopingReviews). In September 2020, we developed a protocol and

150 conducted a search for peer-reviewed, empirical studies that experimentally investigated

151 whether asking participants to make if-then plans improves a measure of sport-related

152 performance. To be eligible, a study had to compare performance in the if-then planning

153 condition to performance in a condition with either another intervention control condition

154 (e.g., setting a performance goal) and/or to a no-treatment control condition. Studies were

155 excluded if they comprised no such control condition (e.g., comparing two different if-then

156 planning conditions). We included quantitative, qualitative, and mixed-method approaches to

157 cover multiple ways in which sport-related performance could be assessed. No further

158 restrictions were made, for instance, regarding the year of publication or participant

159 characteristics.

160 We relied on four different databases (Web of Science, SportDISCUSS, Psyclnfo, and 
161 PubMed) and used the following search string: ("implementation intention*" OR "if-then

162 plan*") AND sport*. The first two authors developed the search string and the first author

163 conducted the search, the results of which were then exported to the reference management

164 software Citavi. Duplicates were removed with the Levenshtein algorithm implemented in

165 Citavi. The resulting list of publications was screened for papers that the authors were aware of

166 but that were missing from the list. The identified records were then reviewed by the first two

167 authors. They selected relevant publications based on the information contained in titles and

168 abstracts. Full texts were then retrieved for the relevant publications and their eligibility for the

169 scoping review was determined by all authors. There were no disagreements among the

170 authors regarding study selection.

171 We used a data-charting form that comprised the following pieces of information (see

172 Table 1): author(s), year of publication, type of sport, sample size (overall and per condition),

173 sample characteristics (athlete vs. student sample, age, gender), content of the if-then planning

174 intervention, type of task, performance and other measure(s), and effects of the intervention.

175 The form was developed by the first author and jointly refined by all authors. The first author

176 charted the data and the results were verified by all authors.

Results

178 The flow of the literature search is depicted in Figure 1. Our search initially identified a

179 total of 106 publications, to which we manually added three publications (109). We then

180 removed 26 duplicates and screened the remaining 83 publications for their content. Several of

181 these publications focused on physical activity rather than a sport-related performance (38) or

182 were in other ways irrelevant for the present review (35; e.g., if-then planning only mentioned, 
183 theoretical contributions). We arrived at a final sample of 10 publications covering $k=11$

184 studies that met our selection criteria and were included in the present review. A complete

185 overview of all identified studies is provided in Table 1, while Table 2 shows the content and

186 structure of the if-then plans. As about half of the studies focus on endurance performance and

187 the other half on a sport-related performance beyond endurance (i.e., tennis, golf, darts,

188 basketball, and volleyball), we structured the results accordingly.

\section{Endurance Performance}

190 One focus of research on if-then planning in sports has been on endurance performance

191 (Wolff, Bieleke, \& Schüler, 2019), which has so far resulted in six published studies (see upper

192 part of Table 1). The majority of these studies focused on static muscular endurance

193 performance, predominantly via weight-holding tasks (Bieleke \& Wolff, 2017; Hirsch et al.,

194 2020; Thürmer et al., 2017; Wolff et al., 2018) and once in a posture-holding yoga task (Wang et

195 al., 2019). Only one study used a cycling task to examine whole-body endurance performance

196 (Latinjak et al., 2018). Common to all studies is their reliance on university student samples

197 from diverse subject domains as well as on laboratory experiments with highly standardized

198 tasks that maximize the internal validity at the expense of the external validity. As perceptions

199 of effort and pain are key challenges to successful endurance performance (e.g., Pageaux,

200 2016), participants were assigned pre-formulated plans that focused on ignoring or managing

201 effort and pain. The main dependent variable in all studies was time-to-failure, in some studies

202 accompanied by ratings of perceived exertion (RPE) and in one study by a measure of activity in 203 the dorsolateral Prefrontal Cortex (dIPFC) as a marker of effortful self-regulation. The central

204 hypothesis was that if-then planning helps participants to deal with negative sensations that 
emerge during the endurance task more effectively, thereby persisting longer than participants

206 in the control conditions.

\section{Main Effects}

Increased time-to-failure in if-then planning versus control conditions has been

209 observed in two studies (Thürmer et al., 2017; Wang et al., 2019). These studies utilized

210 different static muscular endurance tasks (i.e., holding up a heavy ball in a group of three

211 people, holding a difficult yoga posture for as long as possible). The remaining four studies

212 (Bieleke \& Wolff, 2017; Hirsch et al., 2020; Latinjak et al., 2018; Wolff et al., 2018) observed no

213 differences between conditions in a static muscular task (i.e., task, where participants are asked

214 to hold two metal bars that are connected by two intertwined rings for as long as possible,

215 while avoiding contacts between the rings), as well as in a whole-body endurance task (i.e., a

216 time-to-exhaustion cycle ergometer task). Thus, the majority of studies conducted so far

217 indicates that if-then planning does not significantly improve endurance performance.

219 findings were obtained with the same muscular endurance task (Bieleke \& Wolff, 2017; Hirsch

220 et al., 2020; Wolff et al., 2018), which has so far solely been used to study if-then planning

221 effects on endurance. Accordingly, it is unclear whether the failure to observe if-then planning

222 effects might at least partially be attributable to the specific demands of this task. On the other

223 hand, this task constitutes a highly controlled setup, which allows to measure performance with

224 more precision (e.g., errors in task execution) and more rigorously (e.g., preventing

225 compensation movements) than in the studies that yielded significant effects. Second, the

226 studies relied on rather small sample sizes for reliably detecting main effects of if-then 
227 planning. As illustrated in Figure 2, the sample size required to detect common if-then planning

228 effect sizes ranges between 80 and 700 participants in the two-group design most studies relied 229 on (i.e., planning vs. control condition), sample sizes that have not been realized so far in any of 230 the studies included in the current review.

\section{Mechanisms and Moderators}

A major strength of the studies on if-then planning effects on endurance performance is

233 their focus on mechanisms and moderators, which sheds light on the specific conditions under

234 which if-then planning does or does not facilitate sports-related performance. For instance, in

235 the study by Thürmer et al. (2017), both correlational and causal evidence showed that

236 planning to motivate each other by heightening efficacy feelings (i.e., ... then we tell ourselves

237 that we can do it) required that the team members could subsequently interact with each other

238 during the task and cheer each other up. If, however, participants had no adequate means to

239 translate their planned behaviors into action (i.e., they were not allowed to talk to each other),

240 planning did not affect performance in this study.

$241 \quad$ Hirsch et al. (2020) identified people's believes about their own performance limits as

242 another moderator of the effect of if-then planning on sports-related performance. Specifically,

243 the authors found that planning to deal with effort versus pain improved endurance

244 performance among participants who believed that they had not yet fully reached an assumed

245 physical or mental limit of their performance, respectively. Plans that did not fit participants'

246 beliefs in such a manner turned out to be ineffective. Moreover, plans were also found to

247 induce higher levels of perceived exertion under some conditions although they had been

248 designed to optimize dealing with this very sensation (Bieleke \& Wolff, 2017; Latinjak et al., 
249 2018). Finally, on the neuronal level, if-then planning was found to reduce activity in brain

250 regions associated with effortful control (Wolff et al., 2018). More specifically, participants who

251 had formed an if-then plan completed the task with less activity of the lateral Prefrontal Cortex 252 (dIPFC).

253 Beyond Endurance Performance

254 The second focus of research on if-then planning in sports is on sports behavior that

255 does not (primarily) focus on endurance, accumulating to five studies in total (see lower part of

256 Table 1). In contrast to research on endurance performance, these studies have primarily

257 focused on isolated sports-specific performance outcomes within a particular type of sport

258 (e.g., volleyball serves), with the exception of one study that employed a broader focus (i.e., 259 tennis competitions).

260 Two studies relied on university student samples (Stern et al., 2013), whereas three

261 studies focused on athletes in their respective sports: tennis players who participated regularly

262 in competitions across various German tennis leagues (Achtziger et al., 2008), high school

263 students of Swiss volleyball schools with an average training load of about 12 hours/week

264 (Bieleke et al., 2019), and U17 basketball players from several Polish basketball clubs

265 (Wilczynska et al., 2014). In all of these studies, participants generated their plans with the help

266 of the experimenter. In some studies, these self-generated plans focused on how to deal with

267 anticipated negative internal states (e.g., stress, anxiety). Most studies used an objective

268 indicator for successful performance (e.g., successfully serving into the opponent's field) as

269 their main dependent variable, with the exception of one study that measured performance in

270 terms of self- and other reports (Achtziger et al., 2008). 


\section{Main Effects}

Better performance in if-then planning versus control conditions has been reported in

273 three studies (Achtziger et al., 2008; Stern et al., 2013, Studies 1 and 2), while in two studies no

274 such effect was observed (Bieleke et al., 2019; Wilczynska et al., 2014). The studies that

275 reported improved performance adopted plans that focused on regulating negative internal

276 states (e.g., stress, anxiety), whereas participants in the other studies were not using plans with

277 such a focus. In sum, the available evidence tends to favor beneficial effects of if-then planning

278 in non-endurance performance.

279 A striking difference to the endurance domain is the wide variety of tasks that has been

280 used, all of them based on or representing a behavior that reflects a valid sporting situation

281 (e.g., volleyball serves). Also, most studies focused on athletes in their respective sports (e.g.,

282 tennis players in a tennis match). As such, the results have high external validity while still using

283 well-controlled experimental settings. On the downside, the sample sizes were again rather

284 small, which might have made it difficult to reliably establish main effects of if-then planning on

285 performance.

\section{Mechanisms and Moderators}

287 The studies provide several tentative insights into the mechanisms and moderators of if-

288 then planning with regard to sports performance in non-endurance performance domains. For

289 instance, Wilczynska et al. (2014) found no effect of if-then planning on performance in a

290 basketball free-throw test; yet, the authors did observe a lower heart rate among if-then

291 planning participants as compared to control participants. The authors interpreted this finding

292 in terms of a reduced physiological arousal in a potentially stressful situation. While such a 
293 response is not necessarily adaptive, it might improve performance in tasks where high arousal

294 is detrimental. Corroborating this interpretation, Stern et al. (2013) found that planning how to

295 regulate arousing internal states (stress, anxiety) reduced perceptual distortions that often

296 accompany such states of arousal. Specifically, participants in if-then planning conditions

297 perceived the target (Study 1: golf hole, Study 2: dartboard) as being closer than participants in

298 the control conditions; and accordingly they rated the task as easier, which mediated the

299 observed beneficial effects of planning on their performance.

$300 \quad$ Bieleke et al. (2019) demonstrated that if-then plans that targeted the execution of well-

301 learned motor sequences (i.e., volleyball serves) initially interfered with performance. In their

302 study, youth volleyball players who planned how to improve their service performed worse at

303 the beginning of a subsequent series of serves compared to a baseline series; but their

304 performance gradually improved again. Accordingly, potential effects of if-then planning might

305 unfold over time. Alternatively, it is also conceivable that athletes benefit more from planning

306 how to shield the performance of relevant motor sequences from potentially interfering

307 sensations (e.g., Achtziger et al., 2008) than from planning how to execute these sequences in

308 the first place. In addition, objective performance measures and subjective performance ratings

309 by experts might not map on the same thing when it comes to complex motor sequences. In

310 the study by Bieleke et al. (2019) experienced coaches (who were blind to the condition

311 assignment) rated the volleyball serve performance as being better after players had received a

312 self-regulatory intervention (either a goal or an if-then plan), while no such improvement could

313 be observed in the objective performance measures. Even more interestingly, as performance

314 started to improve gradually after the intervention, it is conceivable that the expert coaches 
315 already saw improved performance before it translated into measurable improvements.

\section{Discussion}

If-then planning is a self-regulatory strategy with beneficial effects in many domains of

318 life (Gollwitzer, 2014). While the effectiveness of implementation intentions on PA behavior has

319 been rigorously investigated over the years, recent general reviews of if-then planning research

320 suggest a lack of such evidence in the domain of sports (Bieleke, Keller, \& Gollwitzer, 2021). To

321 address this supposition, we conducted a scoping review of the studies that are available to

322 date in order to stimulate and encourage future research. In a nutshell, we found only very few

323 studies that tested the effects of if-then planning on sport-related performance. Moreover,

324 evidence for the hypothesis that if-then planning improves sports-related performance is rather

325 mixed, with currently more supportive findings emerging in domains that revolve not primarily

326 around endurance (e.g., tennis, golf, darts) than in the domain of endurance performance.

327 These results must be considered as preliminary, however, as they are based on few studies

328 that used rather small and predominantly student samples.

329 Nevertheless, the available studies already shed a nuanced light on potential

330 mechanisms and moderators of if-then planning in sports that might help understand why

331 planning effects were sometimes observed and sometimes not. If-then planning modulated

332 perceptions of exertion and experienced pain in endurance tasks (Bieleke \& Wolff, 2017;

333 Latinjak et al., 2018; Wolff et al., 2018) and attenuated the arousal that accompanied

334 performance in challenging situations (Stern et al., 2013; Wilczynska et al., 2014). This points to

335 various sensations (i.e., effort, pain, arousal) as potential mechanisms of if-then planning

336 effects, and future research might focus on them when investigating how if-then planning 
337 might leverage sports performance. At the same time, the research conducted so far cautions

338 against reliance on if-then plans without considering the specific circumstances that athletes

339 face in sports (i.e., personal and situational factors). For instance, it seems necessary for

340 effective plans to be compatible with exercise-related beliefs about the determinants and limits

341 of performance (Hirsch et al., 2020). Also, care should be taken that exercisers are in a position

342 to translate their planned behaviors into action (Thürmer et al., 2017) and that acting upon

343 them does not interfere with well-elaborated behaviors (Bieleke et al., 2019). Failing to

344 incorporate such insights into the if-then plans might yield unexpected and undesired (i.e.,

345 ironic) effects (Bieleke \& Wolff, 2017), like amplifying attention to a thought that an individual

346 plans to suppress or ignore (akin to the "white bear" effect; e.g., Binsch et al., 2010). Other

347 studies were compatible with the idea that if-then planning automates behavior and reduces

348 effortful control in challenging situations (Stern et al., 2013; Wolff et al., 2018), which should be

349 helpful when these situations are conducive to automaticity but might be disadvantageous

350 when dealing with sensations that must be overridden with effortful force. Specifically, it has

351 been suggested that planning to ignore aversive sensations during an endurance task (i.e.,

352 effort, pain) might backfire by making these sensations more salient while simultaneously

353 throttling the control mechanisms required to deal with them (Wolff et al., 2018). Taken

354 together, even the limited set of studies that has so far investigated if-then planning effects on

355 sport-related performance presents several promising candidates for the moderators and

356 mechanisms that future research might want to focus on. This research might also investigate

357 the mechanisms that are most important for conveying if-then planning effects.

358 The need to investigate the characteristics of situations and individuals that modulate 
359 the effectiveness of if-then planning is not specific to the sports context (Prestwich \& Kellar,

360 2014). For instance, the effects of if-then planning are generally known to depend on the

361 presence of a superordinate goal that is active and valued (Sheeran et al., 2005), which likely

362 applies to sports as well. This could be taken to suggest that future studies should focus more

363 strongly on improving performance among experienced and motivated athletes in their

364 respective sports. On the other hand, research in domains like physical activity and health (e.g.,

365 Hagger et al., 2016; Hagger \& Luszczynska, 2014) also highlight the importance of accounting

366 for moderators that are specific for a certain domain. As such, the initial inconsistencies

367 observed in the present review are part of scientific progress and unavoidable; they constitute

368 an important step to develop tailored and effective if-then planning interventions in sports.

369 Determining the Contents of If-Then Plans

370 It is striking that studies focusing on endurance performance relied primarily on generic

371 plans prescribed by the experimenter, whereas studies focusing on performance in other

372 sports-related domains relied predominantly on individual plans generated by the participants

373 themselves (see Table 1 and 2). This reflects two common approaches in research on if-then

374 planning (Keller et al., 2019). In the domain of sports and in particular when working with

375 experienced athletes, self-generated plans might be better suited as they can take individual

376 differences in relevant personal strengths and weaknesses into account. This might also be a

377 fruitful avenue for research on endurance performance, especially when considering the role of

378 individual beliefs for the effectiveness of if-then plans. For self-generated plans it might

379 additionally be useful to resort to established procedures for eliciting personally relevant

380 contents specified in the if- and then-parts of the plans, thereby maximizing their effects in 
381 future studies. One such procedure is the combination of "mental contrasting and

382 implementation intentions" (MCII; Oettingen, 2014; Oettingen \& Gollwitzer, 2010). With MClI,

383 people first think about their wishes and goals (e.g., improving their performance) and about

384 their obstacles for attaining these goals (e.g., fear of failure). This valuable information about

385 individual obstacles can then be used in the if-then plan, which might specify how to deal

386 effectively with them.

387 Another remarkable feature of the studies reviewed here is that they predominantly

388 revolved around dealing with few negative internal states (e.g., exertion, anxiety). However, it

389 is not clear whether these states are the performance-limiting factors, especially among

390 amateur athletes and exercises. For instance, it has recently been suggested that boredom is a

391 highly relevant internal state that can affect sports performance (Wolff, Bieleke, Martarelli, \&

392 Danckert, 2021). As boredom is closely linked to self-control (Bieleke, Barton, \& Wolff, 2021), it

393 might be promising to investigate whether if-then plans targeting boredom could be more

394 effective than those targeting exertion or anxiety. Moreover, research on if-then planning in

395 sports has so far focused on how to overcome obstacles to good performance. However, if-then

396 plans can also be used to seize good opportunities to attain a goal (Bieleke \& Keller, 2021). A

397 sports-related example is a study showing that planning when and where to drink

398 carbohydrate-electrolyte drinks during stationary cycle ergometer exercise improved

399 physiological markers of hydration (Hagger \& Montasem, 2009). While not directly targeting

400 performance, this study exemplifies the potential benefits that could be reaped by gearing if-

401 then plans in sports to seizing good opportunities for attaining a performance goal. 
Methodological Advances in Future Research

We have argued that the sample sizes of the reviewed studies were rather small

404 throughout, which might have rendered a reliable detection of effects of the size commonly

405 observed in research on if-then planning difficult (see the meta-analysis of existing meta-

406 analyses of if-then planning effects conducted by Keller et al., 2020). In research that focusses

407 on recreational athletes, this shortcoming can be rather easily overcome by increasing sample

408 sizes. This is not the case for research that focuses on elite-level athletes, as this population is

409 notoriously small and difficult to access, making the issue of small sample sizes a rather general

410 one in sport psychology research (Schweizer \& Furley, 2016). Accordingly, future research on if-

411 then planning effects on sport-related performance should also utilize other means to increase

412 statistical power (e.g., Batterham \& Atkinson, 2005): leveraging knowledge about the processes

413 and moderators of if-then planning to maximize its effect, relying on experimental designs with

414 repeated measures to attenuate measurement error, and combining different ways of assessing 415 performance.

416 Another relevant consideration pertains to the observation that people differ in their

417 inclination to engage in if-then planning (Bieleke \& Keller, 2021). These individual differences

418 suggest that some people use if-then plans to enhance their performance (Bieleke \& Keller,

419 2021) and to deal with difficulties of goal attainment (Bieleke, Martarelli, \& Wolff, 2021) even

420 without being prompted to do so. In sports, this could apply in particular to more accomplished

421 athletes who generally tend to score higher on self-control (Englert, 2017; Wolff, Bertrams, \&

422 Schüler, 2019). Accordingly, it seems advisable to take such differences into account when

423 conducting experiments on if-then planning interventions; it can boost statistical power and 
424 allows researchers to gauge the genuine effects of if-then planning interventions. Tentative

425 support for the importance of individual differences in if-then planning in sports is already

426 available: Individuals with a higher propensity to make if-then plans have been shown to be

427 more exercise more (Wolff, Bieleke, Stähler, \& Schüler, 2021).

\section{Practical Implications}

429 We want to address the practical implications of our review for athletes and their

430 coaches. At the bottom line, if-then planning is a simple self-regulatory strategy that can be

431 used to target sports-related performance at virtually no costs. If-then plans are also likely to be

432 in frequent use already, judged by their recommendation in scientific and lay outlets as well as

433 by the evidence for a general inclination to attain goals by making plans. Actually, practitioners

434 have been using if-then plans in their work with athletes for numerous years (Birrer \& Morgan,

435 2010; Samuel et al., 2020). The question of whether if-then plans can reliably improve sports

436 performance cannot be adequately answered yet, as this would require more data gathered

437 systematically from active athletes and in authentic sport environments. However, about half of

438 the studies we have reviewed observed performance improvements, especially when the

439 sporting tasks did not call for the regulation of pain or effort. And importantly, the remaining

440 studies only found no effects of if-then planning rather than detrimental ones, suggesting that

441 unintended effects are unlikely to adversely affect performance. Athletes and coaches might

442 thus experiment with if-then plans to enhance sports performance, while researchers continue

443 to work on advancing our understanding of how if-then plans should be optimally devised for 444 this purpose. 
447 Aarts, H., Dijksterhuis, A. \& Midden, C. (1999). To plan or not to plan? Goal achievement or

448 interrupting the performance of mundane behaviors. European Journal of Social Psychology,

449 29, 971-979. https://doi.org/10.1002/(SICI)1099-0992(199912)29:8<971::AID-

$450 \quad$ EJSP963>3.0.CO;2-A

451 Achtziger, A., Bayer, U. C. \& Gollwitzer, P. M. (2012). Committing to implementation intentions:

452 Attention and memory effects for selected situational cues. Motivation and Emotion, 36,

453 287-300. https://doi.org/10.1007/S11031-011-9261-6

454 Achtziger, A., Gollwitzer, P. M. \& Sheeran, P. (2008). Implementation intentions and shielding

455 goal striving from unwanted thoughts and feelings. Personality \& Social Psychology Bulletin,

456 34, 381-393. https://doi.org/10.1177/0146167207311201

457 Bali, A. (2015). Psychological factors affecting sports performance. International Journal of

$458 \quad$ Physical Education, Sports and Health, 1, 92-95.

459 Batterham, A. M. \& Atkinson, G. (2005). How big does my sample need to be? A primer on the

460 murky world of sample size estimation. Physical Therapy in Sport, 6, 153-163.

461 https://doi.org/10.1016/i.ptsp.2005.05.004

462 Bayer, U. C., Achtziger, A., Gollwitzer, P. M. \& Moskowitz, G. B. (2009). Responding to 463 subliminal cues: Do if-then plans facilitate action preparation and initiation without 464 conscious intent? Social Cognition, 27, 183-201. https://doi.org/10.1521/soco.2009.27.2.183

465 Bélanger-Gravel, A., Godin, G. \& Amireault, S. (2013). A meta-analytic review of the effect of 466 implementation intentions on physical activity. Health Psychology Review, 7, 23-54.

$467 \quad$ https://doi.org/10.1080/17437199.2011.560095 
468 Bieleke, M., Barton, L. \& Wolff, W. (2021). Trajectories of boredom in self-control demanding $469 \quad$ tasks. Cognition and Emotion. Advance online publication. https://doi.org/10.1080/02699931.2021.1901656

471 Bieleke, M., Dohmen, D. \& Gollwitzer, P. M. (2020). Effects of social value orientation (SVO) and 472 decision mode on controlled information acquisition-A Mouselab perspective. Journal of 473 Experimental Social Psychology, 86, 103896. https://doi.org/10.1016/j.jesp.2019.103896

474 Bieleke, M. \& Keller, L. (2021). Individual differences in if-then planning: Insights from the 475 development and application of the if-then planning scale (ITPS). Personality and Individual 476 Differences, 170, 110500. https://doi.org/10.1016/i.paid.2020.110500

477 Bieleke, M., Keller, L. \& Gollwitzer, P. M. (2021). If-then planning. European Review of Social 478 Psychology, 32, 88-122. https://doi.org/10.1080/10463283.2020.1808936

479 Bieleke, M., Kriech, C. \& Wolff, W. (2019). Served well? A pilot field study on the effects of 480 conveying self-control strategies on volleyball service Performance. Behavioral Sciences, 9.

$481 \quad \underline{\text { https://doi.org/10.3390/bs9090093 }}$

482 Bieleke, M., Martarelli, C. \& Wolff, W. (2021). If-then planning, self-control, and boredom as 483 predictors of adherence to social distancing guidelines: Evidence from a two-wave $484 \quad$ longitudinal study with a behavioral intervention. PsyArXiv. https://doi.org/10.31234/osf.io/enzbv

486 Bieleke, M. \& Wolff, W. (2017). That escalated quickly-Planning to ignore RPE can backfire. 487 Frontiers in Physiology, 8, 736. https://doi.org/10.3389/fphys.2017.00736 488 Binsch, O., Oudejans, R. R. D., Bakker, F. C. \& Savelsbergh, G. J. P. (2010). Ironic effects and final 

target fixation in a penalty shooting task. Human Movement Science, 29, 277-288. https://doi.org/10.1016/i.humov.2009.12.002

491 Birrer, D. \& Morgan, G. (2010). Psychological skills training as a way to enhance an athlete's

492 performance in high-intensity sports. Scandinavian Journal of Medicine \& Science in Sports, 20, 78-87. https://doi.org/10.1111/j.1600-0838.2010.01188.x

494 Brandstätter, V., Lengfelder, A. \& Gollwitzer, P. M. (2001). Implementation intentions and 495 efficient action initiation. Journal of Personality and Social Psychology, 81, 946-960.

$496 \quad$ https://doi.org/10.1037/0022-3514.81.5.946

497 Brick, N. E., Maclntyre, T. E. \& Campbell, M. J. (2016). Thinking and action: A cognitive 498 perspective on self-regulation during endurance performance. Frontiers in Physiology, 7, 499 159. https://doi.org/10.3389/fphys.2016.00159

500 Calder, A. (2009). Fatigue is no foe with recovery strategies. Australian Sports Commission. 501 http://www.ausport.gov.au/sportsofficialmag/physical preparation/fatigue is no foe 502 da Silva, M. A. V., São-João, T. M., Brizon, V. C., Franco, D. H. \& Mialhe, F. L. (2018). Impact of 503 implementation intentions on physical activity practice in adults: A systematic review and 504 meta-analysis of randomized clinical trials. PloS One, 13, e0206294.

$505 \quad \underline{\text { https://doi.org/10.1371/journal.pone.0206294 }}$

506 Englert, C. (2016). The strength model of self-control in sport and exercise psychology. Frontiers 507 in Psychology, 7, 179. https://doi.org/10.3389/fpsyg.2016.00314

508 Englert, C. (2017). Ego depletion in sports: Highlighting the importance of self-control strength 509 for high-level sport performance. Current Opinion in Psychology, 16, 1-5. 
511 Englert, C. (2019). The self-regulation of human performance: A critical discussion and future

512 directions for self-control research. Performance Enhancement \& Health, 6, 156-157.

$513 \quad$ https://doi.org/10.1016/j.peh.2019.04.001

514 Englert, C. \& Rummel, J. (2016). I want to keep on exercising but I don't: The negative impact of

515 momentary lacks of self-control on exercise adherence. Psychology of Sport and Exercise, 26,

516 24-31. https://doi.org/10.1016/j.psychsport.2016.06.001

517 Faul, F., Erdfelder, E., Lang, A.-G. \& Buchner, A. (2007). G*power 3: A flexible statistical power 518 analysis program for the social, behavioral, and biomedical sciences. Behavior Research

519 Methods, 39, 175-191. https://doi.org/10.3758/bf03193146

520 Franck, A., Stambulova, N. B. \& Ivarsson, A. (2018). Swedish athletes' adjustment patterns in

521 the junior-to-senior transition. International Journal of Sport and Exercise Psychology, 16,

522 398-414. https://doi.org/10.1080/1612197X.2016.1256339

523 Gollwitzer, P. M. (1999). Implementation intentions: Strong effects of simple plans. American

524 Psychologist, 54, 493-503. https://doi.org/10.1037/0003-066X.54.7.493

525 Gollwitzer, P. M. (2014). Weakness of the will: Is a quick fix possible? Motivation and Emotion, 526 38, 305-322. https://doi.org/10.1007/s11031-014-9416-3

527 Gollwitzer, P. M. \& Brandstätter, V. (1997). Implementation intentions and effective goal

528 pursuit. Journal of Personality and Social Psychology, 73, 186-199.

$529 \quad$ https://doi.org/10.1037/0022-3514.73.1.186

530 Gollwitzer, P. M. \& Oettingen, G. (2011). Planning promotes goal striving. In K. D. Vohs \& R. F. 
531 Baumeister (Eds.), Handbook of self-regulation: Research, theory, and applications (pp. 162-

532 185). Guilford Press.

533 Gollwitzer, P. M. \& Sheeran, P. (2006). Implementation intentions and goal achievement: A

534 meta-analysis of effects and processes. Advances in Experimental Social Psychology, 38, 69-

535 119. https://doi.org/10.1016/S0065-2601(06)38002-1

536 Gregoire, C. (2016). Why runners 'hit the wall', and what to do about it.

537 https://www.huffpost.com/entry/runners-psychological-mental-

538 obstacles n 58484917e4b08c82e8893393?guccounter=1

539 Hagger, M. S. \& Luszczynska, A. (2014). Implementation intention and action planning

540 interventions in health contexts: State of the research and proposals for the way forward.

541 Applied Psychology: Health and Well-Being, 6, 1-47. https://doi.org/10.1111/aphw.12017

542 Hagger, M. S., Luszczynska, A., Wit, J. de, Benyamini, Y., Burkert, S., Chamberland, P.-E.,

543 Chater, A., Dombrowski, S. U., van Dongen, A., French, D. P., Gauchet, A., Hankonen, N.,

544 Karekla, M., Kinney, A. Y., Kwasnicka, D., Hing Lo, S., López-Roig, S., Meslot, C.,

545 Marques, M. M., . . . Gollwitzer, P. M. (2016). Implementation intention and planning

546 interventions in Health Psychology: Recommendations from the Synergy Expert Group for

547 research and practice. Psychology \& Health, 31, 814-839.

$548 \quad$ https://doi.org/10.1080/08870446.2016.1146719

549 Hagger, M. S. \& Montasem, A. (2009). Implementing intentions to drink a carbohydrate-

550 electrolyte solution during exercise. Journal of Sports Sciences, 27, 963-974.

$551 \quad \underline{\text { https://doi.org/10.1080/02640410902998262 }}$

552 Hirsch, A., Bieleke, M., Schüler, J. \& Wolff, W. (2020). Implicit theories about athletic ability 
modulate the effects of if-then planning on performance in a standardized endurance task.

$554 \quad$ International Journal of Environmental Research and Public Health, 17, 2576.

$555 \quad$ https://doi.org/10.3390/ijerph17072576

556 Janczyk, M., Dambacher, M., Bieleke, M. \& Gollwitzer, P. M. (2015). The benefit of no choice:

557 Goal-directed plans enhance perceptual processing. Psychological Research, 79, 206-220.

$558 \quad$ https://doi.org/10.1007/s00426-014-0549-5

559 Jones, M. V. (2003). Controlling emotions in sport. The Sport Psychologist, 17, 471-486.

$560 \quad$ https://doi.org/10.1123/TSP.17.4.471

561 Keller, L., Bieleke, M. \& Gollwitzer, P. M. (2019). Mindset theory of action phases and if-then

562 planning. In K. Sassenberg \& M. L. Vliek (Eds.), Social psychology in action: Evidence-based

563 interventions from theory to practice (pp. 23-37). Springer. https://doi.org/10.1007/978-3-

$564 \quad \underline{030-13788-5 \quad 2}$

565 Keller, L., Gollwitzer, P. M. \& Sheeran, P. (2020). Changing behavior using the model of action

566 phases. In M. S. Hagger, K. Hamilton, N. Hankonen \& T. Lintunen (Eds.), The handbook of

567 behavior change (pp. 77-88). Cambridge University Press.

$568 \quad$ https://doi.org/10.1017/9781108677318.006

569 Latinjak, A. T., Las Heras, B. de, Sacot, A., Fernandez, D., Robinson, D. \& Lane, A. M. (2018).

570 Effects of reflection to improve goal-directed self-talk on endurance performance. Sports, 6.

$571 \quad \underline{\text { https://doi.org/10.3390/sports6020055 }}$

572 Legrand, E., Bieleke, M., Gollwitzer, P. M. \& Mignon, A. (2017). Nothing will stop me? Flexibly

573 tenacious goal striving with implementation intentions. Motivation Science, 3, 101-118.

$574 \quad$ https://doi.org/10.1037/mot0000050 
575 Martiny-Huenger, T., Bieleke, M., Oettingen, G. \& Gollwitzer, P. M. (2016). From thought to

576 automatic action: Strategic and spontaneous action control by if-then planning. In R.

577 Deutsch, B. Gawronski \& W. Hofmann (Eds.), Reflective and impulsive determinants of

578 human behavior (pp. 69-84). Routledge.

579 McCormick, A., Meijen, C. \& Marcora, S. (2018). Psychological demands experienced by

580 recreational endurance athletes. International Journal of Sport and Exercise Psychology, 16,

581 415-430. https://doi.org/10.1080/1612197X.2016.1256341

582 Milne, S., Orbell, S. \& Sheeran, P. (2002). Combining motivational and volitional interventions to

583 promote exercise participation: Protection motivation theory and implementation

584 intentions. British Journal of Health Psychology, 7, 163-184.

$585 \quad$ https://doi.org/10.1348/135910702169420

586 Oettingen, G. (2014). Rethinking positive thinking: Inside the new science of motivation. Penguin 587 Random House.

588 Oettingen, G. \& Gollwitzer, P. M. (2010). Strategies of setting and implementing goals: Mental

589 contrasting and implementation intentions. In J. E. Maddux \& J. P. Tangney (Eds.), Social

590 psychological foundations of clinical psychology (pp. 114-135). The Guilford Press.

591 Pageaux, B. (2016). Perception of effort in exercise science: Definition, measurement and

592 perspectives. European Journal of Sport Science, 16, 885-894.

$593 \quad$ https://doi.org/10.1080/17461391.2016.1188992

594 Prestwich, A. \& Kellar, I. (2014). How can the impact of implementation intentions as a

595 behaviour change intervention be improved? European Review of Applied Psychology, 64,

596 35-41. https://doi.org/10.1016/j.erap.2010.03.003 
597 Rhodes, R. E. \& Bruijn, G.-J. de (2013). How big is the physical activity intention-behaviour gap?

598 A meta-analysis using the action control framework. British Journal of Health Psychology, 18, 599 296-309. https://doi.org/10.1111/bjhp.12032

600 Samuel, R. D., Gal, S., Matzkin, G. \& Englert C. (2020). The “10 Mentality:” A longitudinal case 601 study of self-control strength in two competitive recurve archers. Case Studies in Sport and 602 Exercise Psychology, 4, 142-151. https://doi.org/10.1123/cssep.2020-0021

603 Schweiger Gallo, I., Keil, A., McCulloch, K. C., Rockstroh, B. \& Gollwitzer, P. M. (2009). Strategic 604 automation of emotion regulation. Journal of Personality and Social Psychology, 96, 11-31. $605 \quad \underline{\text { https://doi.org/10.1037/a0013460 }}$

606 Schweizer, G. \& Furley, P. (2016). Reproducible research in sport and exercise psychology: The 607 role of sample sizes. Psychology of Sport and Exercise, 23, 114-122.

$608 \quad \underline{\text { https://doi.org/10.1016/j.psychsport.2015.11.005 }}$

609 Sheeran, P. \& Webb, T. L. (2016). The intention-behavior gap. Social and Personality Psychology 610 Compass, 10, 503-518. https://doi.org/10.1111/SPC3.12265

611 Sheeran, P., Webb, T. L. \& Gollwitzer, P. M. (2005). The interplay between goal intentions and 612 implementation intentions. Personality \& Social Psychology Bulletin, 31, 87-98.

$613 \quad$ https://doi.org/10.1177/0146167204271308

614 Stern, C., Cole, S., Gollwitzer, P. M., Oettingen, G. \& Balcetis, E. (2013). Effects of 615 implementation intentions on anxiety, perceived proximity, and motor performance.

616 Personality \& Social Psychology Bulletin, 39, 623-635.

617 https://doi.org/10.1177/0146167213479612 
618 Thürmer, J. L., Bieleke, M., Wieber, F. \& Gollwitzer, P. M. (2020). If-then plans help regulate

619 automatic peer influence on impulse buying. European Journal of Marketing, 54, 2079-2105.

$620 \quad$ https://doi.org/10.1108/EJM-05-2018-0341

621 Thürmer, J. L., Wieber, F. \& Gollwitzer, P. M. (2017). Planning and performance in small groups:

622 Collective implementation intentions enhance group goal striving. Frontiers in Psychology, 8, 623 603. https://doi.org/10.3389/fpsyg.2017.00603

624 Tricco, A. C., Lillie, E., Zarin, W., O’Brien, K. K., Colquhoun, H., Levac, D., Moher, D.,

625 Peters, M. D. J., Horsley, T., Weeks, L., Hempel, S., Akl, E. A., Chang, C., McGowan, J.,

626 Stewart, L., Hartling, L., Aldcroft, A., Wilson, M. G., Garritty, C., . . Straus, S. E. (2018). Prisma

627 extension for scoping reviews (PRISMA-ScR): Checklist and explanation. Annals of Internal

628 Medicine, 169, 467-473. https://doi.org/10.7326/M18-0850

629 Wang, S., Xu, J., Yu, Q. \& Zhou, J. (2019). Implementation intentions improve exercise self-

630 efficacy and exercise behavior regardless of task difficulty. Social Behavior and Personality:

631 An International Journal, 47, 1-13. https://doi.org/10.2224/sbp.8000

632 Webb, T. L. \& Sheeran, P. (2003). Can implementation intentions help to overcome ego-

633 depletion? Journal of Experimental Social Psychology, 39, 279-286.

$634 \quad$ https://doi.org/10.1016/S0022-1031(02)00527-9

635 Webb, T. L. \& Sheeran, P. (2004). Identifying good opportunities to act: Implementation

636 intentions and cue discrimination. European Journal of Social Psychology, 34, 407-419.

$637 \quad \underline{\text { https://doi.org/10.1002/EJSP.205 }}$

638 Webb, T. L. \& Sheeran, P. (2007). How do implementation intentions promote goal attainment? 639 A test of component processes. Journal of Experimental Social Psychology, 43, 295-302. 

https://doi.org/10.1016/J.JESP.2006.02.001

641 Wilczynska, D., Lipinska, P. \& Wolujewicz-Czerlonko, M. (2014). The influence of intention

642 implementation on throw effectiveness of young basketball players. Baltic Journal of Health

643 and Physical Activity, 6. https://doi.org/10.2478/bjha-2014-0029

644 Wolff, W., Bertrams, A. \& Schüler, J. (2019). Trait self-control discriminates between youth

645 football players selected and not selected for the German talent program: A Bayesian

646 analysis. Frontiers in Psychology, 10, 2203. https://doi.org/10.3389/fpsyg.2019.02203

647 Wolff, W., Bieleke, M., Hirsch, A., Wienbruch, C., Gollwitzer, P. M. \& Schüler, J. (2018). Increase 648 in prefrontal cortex oxygenation during static muscular endurance performance is

649 modulated by self-regulation strategies. Scientific Reports, 8, 15756.

$650 \quad$ https://doi.org/10.1038/s41598-018-34009-2

651 Wolff, W., Bieleke, M., Martarelli, C. S. \& Danckert, J. (2021). A primer on the role of boredom

652 in self-controlled sports and exercise behavior. Frontiers in Psychology, 12, 637839.

$653 \quad$ https://doi.org/10.3389/fpsyg.2021.637839

654 Wolff, W., Bieleke, M. \& Schüler, J. (2019). Goal striving and endurance performance. In C.

655 Meijen (Ed.), Endurance performance in sport: Psychological theory and interventions

656 (pp. 125-137). Routledge.

657 Wolff, W., Bieleke, M., Stähler, J. \& Schüler, J. (2021). Too bored for sports? Adaptive and non658 adaptive latent personality profiles for exercise behavior. Psychology of Sport and Exercise, 659 53, 101851. https://doi.org/10.1016/j.psychsport.2020.101851

660 Wolff, W., Hirsch, A., Bieleke, M. \& Shenhav, A. (2021). Neuroscientific approaches to self- 
661 regulatory control in sports. In C. Englert \& I. Taylor (Eds.), Handbook of self-regulation and

662 motivation in sport and exercise (pp. 149-165). Routledge. 
Table 1

Overview of Studies on If-Then Planning Effects in Sports

\begin{tabular}{|c|c|c|c|c|c|c|}
\hline Study & Topic & $\begin{array}{l}\text { Sample Size } \\
\text { (Condition) }\end{array}$ & Sample Characteristics & Intervention & Task (Measures) & $\begin{array}{l}\text { If-then Planning Main } \\
\text { Effects }\end{array}$ \\
\hline \multicolumn{7}{|c|}{ Endurance Performance } \\
\hline $\begin{array}{l}\text { Bieleke and } \\
\text { Wolff (2017) }\end{array}$ & $\begin{array}{l}\text { Weight- } \\
\text { holding }\end{array}$ & $\begin{array}{l}62 \text { (plan: 29, } \\
\text { goal: } 33 \text { ) }\end{array}$ & $\begin{array}{l}\text { university students, } M=24 \\
\text { years, all female }\end{array}$ & $\begin{array}{l}\text { plan to continue } \\
\text { despite exertion }\end{array}$ & $\begin{array}{l}\text { hold rings while avoiding } \\
\text { contacts between them (time- } \\
\text { to-failure, errors, RPE) }\end{array}$ & $\begin{array}{l}\text { no effect on } \\
\text { performance, faster } \\
\text { increase of RPE }\end{array}$ \\
\hline $\begin{array}{l}\text { Thürmer et al. } \\
\text { (2017, Study 1) }\end{array}$ & $\begin{array}{l}\text { Weight- } \\
\text { holding }\end{array}$ & $\begin{array}{l}47 \text { triads (plan: } \\
21, \text { goal: } 26 \text { ) }\end{array}$ & $\begin{array}{l}\text { university students, } M=23 \\
\text { years, } 75 \% \text { female }\end{array}$ & $\begin{array}{l}\text { plan to deal with pain } \\
\text { by self-affirmation }\end{array}$ & $\begin{array}{l}\text { hold ball simultaneously as a } \\
\text { triad (time-to-failure) }\end{array}$ & increased time-to-failure \\
\hline $\begin{array}{l}\text { Latinjak et al. } \\
\text { (2018) }\end{array}$ & Cycling & $\begin{array}{l}27 \text { (plan: 15, } \\
\text { control: } 12 \text { ) }\end{array}$ & $\begin{array}{l}\text { sport students, } M=22 \text { years, } \\
41 \% \text { female }\end{array}$ & Self-generated plans & $\begin{array}{l}\text { Cycle endurance test (time-to- } \\
\text { failure, RPE) }\end{array}$ & $\begin{array}{l}\text { no effect on } \\
\text { performance, increased } \\
\text { RPE }\end{array}$ \\
\hline $\begin{array}{l}\text { Wolff et al. } \\
\text { (2018) }\end{array}$ & $\begin{array}{l}\text { Weight- } \\
\text { holding }\end{array}$ & $\begin{array}{l}60 \text { (plan: 30, } \\
\text { control: 30) }\end{array}$ & $\begin{array}{l}\text { university students, } M=22 \\
\text { years, all female }\end{array}$ & $\begin{array}{l}\text { plan to continue } \\
\text { despite exertion }\end{array}$ & $\begin{array}{l}\text { hold rings avoiding contacts } \\
\text { (time-to-failure, errors, DLPFC } \\
\text { activity) }\end{array}$ & $\begin{array}{l}\text { no effect on } \\
\text { performance and RPE, } \\
\text { reduced DLPFC activity }\end{array}$ \\
\hline $\begin{array}{l}\text { Wang et al. } \\
\text { (2019) }\end{array}$ & Yoga & $\begin{array}{l}90 \text { (plan: } 30, \\
\text { goal: } 30, \text { control: } \\
30)\end{array}$ & $\begin{array}{l}\text { high school students, } M=16 \\
\text { years, } 53 \% \text { female }\end{array}$ & $\begin{array}{l}\text { plan to continue } \\
\text { despite pain }\end{array}$ & $\begin{array}{l}\text { holding a yoga posture (time- } \\
\text { to-failure) }\end{array}$ & increased time-to-failure \\
\hline $\begin{array}{l}\text { Hirsch et al. } \\
(2020)\end{array}$ & $\begin{array}{l}\text { Weight- } \\
\text { holding }\end{array}$ & $\begin{array}{l}66 \text { (plan: 33, } \\
\text { goal: 33) }\end{array}$ & $\begin{array}{l}\text { university students, } M=26 \\
\text { years, all male }\end{array}$ & $\begin{array}{l}\text { plan to continue } \\
\text { despite either exertion } \\
\text { or pain }\end{array}$ & $\begin{array}{l}\text { hold rings avoiding contacts } \\
\text { (time-to-failure, errors, RPE) }\end{array}$ & $\begin{array}{l}\text { no effects on } \\
\text { performance and RPE }\end{array}$ \\
\hline \multicolumn{7}{|c|}{ Beyond Endurance Performance } \\
\hline $\begin{array}{l}\text { Achtziger et al. } \\
\text { (2008, Study } 2 \text { ) }\end{array}$ & Tennis & $\begin{array}{l}107 \text { (plan: } 37 \text {, } \\
\text { goal: } 38, \text { control: } \\
32 \text { ) }\end{array}$ & $\begin{array}{l}\text { tennis players, } M=34 \text { years, } \\
29 \% \text { female }\end{array}$ & $\begin{array}{l}\text { self-generated plans } \\
\text { focusing on negative } \\
\text { inner states }\end{array}$ & $\begin{array}{l}\text { tennis match (rating of } \\
\text { performance and fitness) }\end{array}$ & $\begin{array}{l}\text { higher fitness and } \\
\text { performance ratings }\end{array}$ \\
\hline $\begin{array}{l}\text { Stern et al. } \\
(2013, \text { Study 1) }\end{array}$ & Golf & $\begin{array}{l}48 \text { (plan: } 24, \\
\text { control: } 24)\end{array}$ & $\begin{array}{l}\text { university students and } \\
\text { community members, } M= \\
23 \text { years, } 77 \% \text { female }\end{array}$ & $\begin{array}{l}\text { self-generated plans } \\
\text { focusing on anxiety- } \\
\text { related states }\end{array}$ & $\begin{array}{l}\text { putting shots into golf hole } \\
\text { (success) }\end{array}$ & higher success rate \\
\hline $\begin{array}{l}\text { Stern et al. } \\
(2013, \text { Study 2) }\end{array}$ & Darts & $\begin{array}{l}93 \text { (plan: } 31, \\
\text { goal: } 30, \text { control: } \\
32 \text { ) }\end{array}$ & $\begin{array}{l}\text { university students, } M=20 \\
\text { years, } 66 \% \text { female }\end{array}$ & $\begin{array}{l}\text { self-generated plans } \\
\text { focusing on anxiety- } \\
\text { related states }\end{array}$ & $\begin{array}{l}\text { throwing darts on center circle } \\
\text { (success) }\end{array}$ & higher success rate \\
\hline $\begin{array}{l}\text { Wilczynska et } \\
\text { al. (2014) }\end{array}$ & Basketball & $\begin{array}{l}76 \text { (plan: } 38, \\
\text { control: 38) }\end{array}$ & $\begin{array}{l}\text { basketball players, } M=15 \\
\text { years, } 42 \% \text { female }\end{array}$ & self-generated plans & $\begin{array}{l}\text { throw effectiveness test } \\
\text { (throwing success, heart rate) }\end{array}$ & $\begin{array}{l}\text { no effect on success, } \\
\text { reduced heart rate }\end{array}$ \\
\hline $\begin{array}{l}\text { Bieleke et al. } \\
\text { (2019) }\end{array}$ & Volleyball & $\begin{array}{l}62 \text { (plan: 33, } \\
\text { goal: } 29 \text { ) }\end{array}$ & $\begin{array}{l}\text { volleyball players, } M=14 \\
\text { years, } 44 \% \text { female }\end{array}$ & $\begin{array}{l}\text { self-generated plans } \\
\text { based on coach } \\
\text { feedback }\end{array}$ & $\begin{array}{l}\text { Serve ball to target position } \\
\text { (error, velocity, precision) }\end{array}$ & $\begin{array}{l}\text { no effects on } \\
\text { performance indicators }\end{array}$ \\
\hline
\end{tabular}


Table 2

\begin{tabular}{|c|c|}
\hline Study & If-then Planning Intervention \\
\hline \multicolumn{2}{|l|}{ Endurance Performance } \\
\hline $\begin{array}{l}\text { Bieleke and Wolff } \\
\text { (2017) }\end{array}$ & $\begin{array}{l}\text { Participants received the following if-then plan from the experimenter: "If the task becomes too strenuous for me, } \\
\text { then I ignore the strain and tell myself: Keep going" }\end{array}$ \\
\hline $\begin{array}{l}\text { Thürmer et al. } \\
(2017, \text { Study } 1)\end{array}$ & $\begin{array}{l}\text { Participants received the following plan either in an individual (I) or a collective (We) format: "And if my (our) } \\
\text { muscles hurt, then I (we) will ignore the pain and tell myself (ourselves): I (We) can do it" }\end{array}$ \\
\hline Latinjak et al. (2018) & $\begin{array}{l}\text { Participants generated their own if-then plans by anticipating problematic situations (e.g., disengagement thoughts, } \\
\text { dejection, fatigue) and specifying a goal-directed behaviors. }\end{array}$ \\
\hline Wolff et al. (2018) & $\begin{array}{l}\text { Participants received the following if-then plan from the experimenter: "If the task becomes too strenuous for me, } \\
\text { then I will ignore the strain and tell myself: Keep going" }\end{array}$ \\
\hline Wang et al. (2019) & $\begin{array}{l}\text { Participants generated their own if-then plans. Example: "If I tremble and am in pain, I will encourage myself to } \\
\text { persevere and keep counting up to } 90 \text { " }\end{array}$ \\
\hline Hirsch et al. (2020) & $\begin{array}{l}\text { Participants received the following if-then plan from the experimenter: "And if my exertion (pain) becomes too high, } \\
\text { then I tell myself: I can still keep going" }\end{array}$ \\
\hline \multicolumn{2}{|c|}{ Beyond Endurance Performance } \\
\hline $\begin{array}{l}\text { Achtziger et al. } \\
\text { (2008, Study } 2)\end{array}$ & $\begin{array}{l}\text { Participants generated their own if-then plans by specifying inner states (e.g., "not concentrating enough", "feeling } \\
\text { self-abandoned", "feeling exhausted", "feeling angry") and goal-directed behaviors (e.g., "then I will risk something } \\
\text { and play courageously," "then I will calm myself and tell myself 'I will win!'”) from prepared lists of inner states and } \\
\text { behaviors. }\end{array}$ \\
\hline $\begin{array}{l}\text { Stern et al. (2013, } \\
\text { Study } 1 \text { \& 2) }\end{array}$ & $\begin{array}{l}\text { Participants generated their own if-then plans by specifying four negative inner states that might be detrimental for } \\
\text { the upcoming task and linking them to goal-directed behaviors. Example: "If I feel irritated, then I will tell myself to } \\
\text { relax" }\end{array}$ \\
\hline $\begin{array}{l}\text { Wilczynska et al. } \\
\text { (2014) }\end{array}$ & Participants generated their own if-then plans with the help of an experimenter. No examples are given. \\
\hline Bieleke et al. (2019) & $\begin{array}{l}\text { Participants received if-then plans that were developed by an experimenter based on individual feedback of their } \\
\text { coaches, who had observed their previous service performance. Examples: "When I serve, then I tighten my hand and } \\
\text { fingers", "When I approach the ball, then I take a small step first", and "When I make the service, then I throw the } \\
\text { ball higher up" }\end{array}$ \\
\hline
\end{tabular}


Figure 1

670 PRISMA Flow Chart Illustrating the Literature Search for the Scoping Review

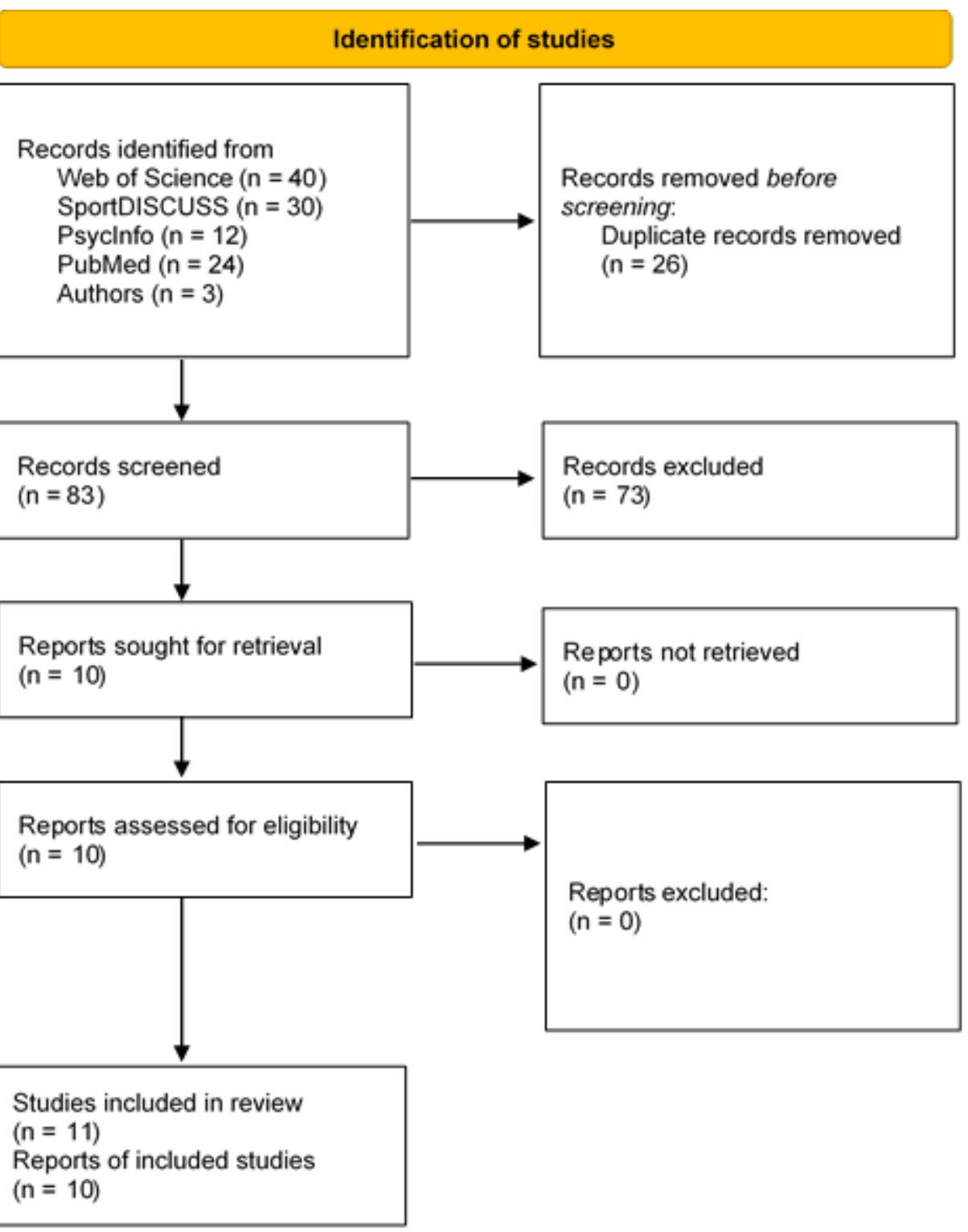

671
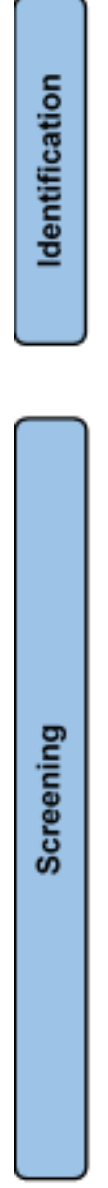

\section{Records screened} $(n=83)$

Records excluded

$(n=73)$

Reports of included studies

$(n=10)$ 
673 Required Sample Sizes to Detect Main If-Then Planning Effects in a Two-Group Design With 80\%

674 and 90\% Power

675

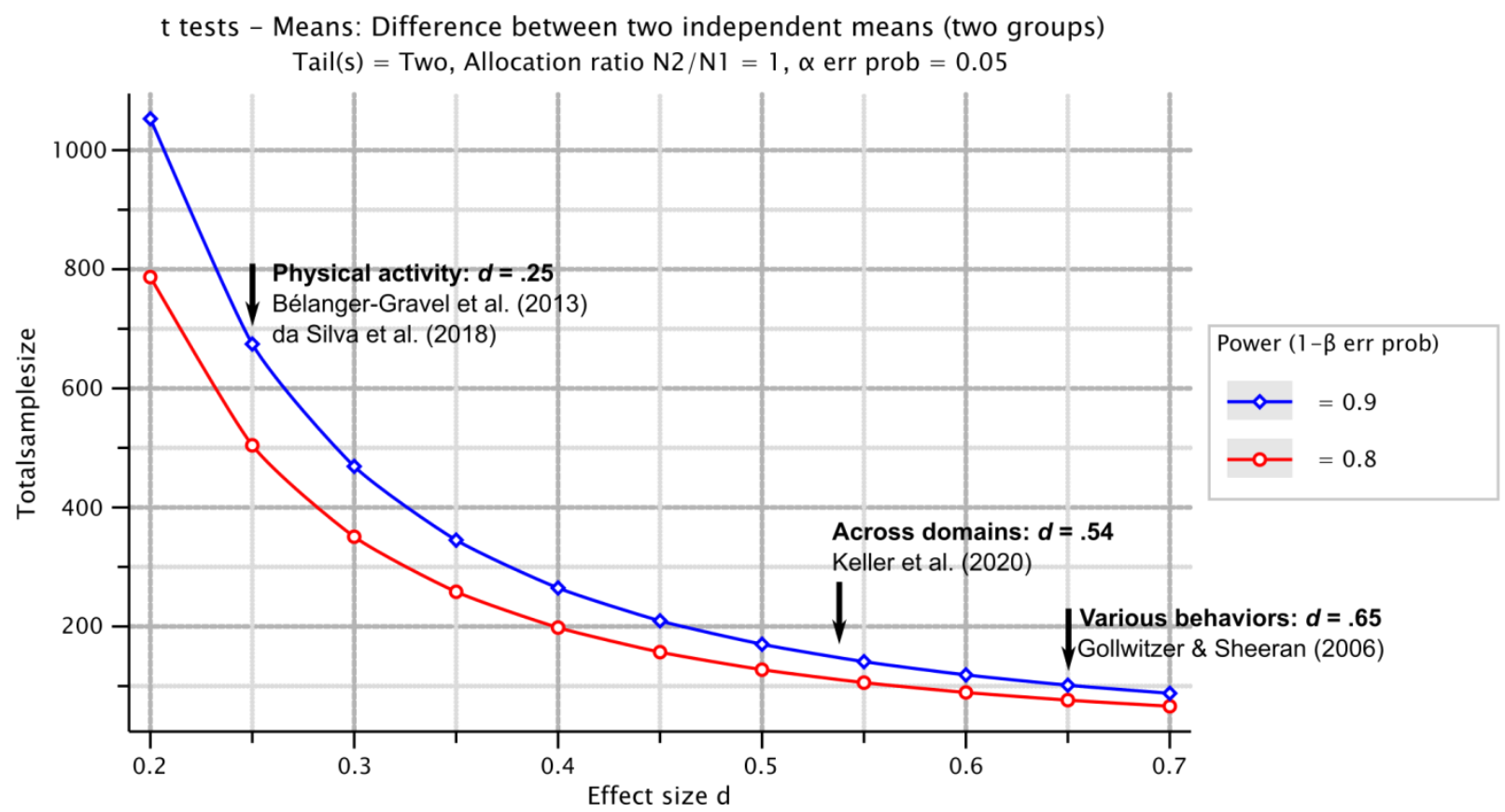

Note. This figure has been created with G*Power (version 2.1.9.2; Faul et al., 2007). It shows how the required total sample size ( $y$-axis) changes as a function of the effect size ( $x$-axis), once for a test power of $80 \%$ (red line, circles) and once for a power of $90 \%$ (blue line, diamonds). For instance, an experiment with two independent groups (control vs. implementation intention) would require a total sample size of about 500 participants to detect a small effect of $d=.25$ with $80 \%$ power and about 675 participants to achieve $90 \%$ power. For detecting a medium-tolarge effect of $d=.65$ it would be necessary to recruit about 80 participants to achieve $80 \%$ power and about 100 participants to achieve $90 \%$ power. The effect sizes found in three metaanalyses on implementation intentions effects are highlighted with arrows: an initial metaanalysis reported by Gollwitzer \& Sheeran (2006) covering various domains, two meta-analyses on implementation intentions effects in the domain of physical activity (Bélanger-Gravel et al., 2013; da Silva et al., 2018), and a recent meta-analysis of meta-analyses (Keller et al., 2020). 